\title{
Graft copolymerization of MMA onto flax under different reaction conditions: a comparative study
}

\author{
B. S. Kaith ${ }^{1}$, S. Kalia ${ }^{*}$ \\ ${ }^{1}$ Department of Chemistry, Dr. B.R. Ambedkar National Institute of Technology (Deemed University), \\ Jalandhar - $144001(\mathrm{~Pb}$.) India \\ ${ }^{2}$ Department of Chemistry, Singhania University, Pacheri Badi - 333515 Jhunjhunu (Rajasthan) India
}

Received 26 October 2007; accepted in revised form 21 December 2007

\begin{abstract}
In the present paper, grafting of methyl methacrylate (MMA) onto flax fiber was carried-out under different reaction condition such as in air (IA), under pressure (UP) and under the influence of micro-wave radiations (MWR). Maximum percentage grafting $\left(41.7 \%\right.$ ) has been observed in case of graft copolymerization carried-out in air at $55^{\circ} \mathrm{C}$ followed by grafting under pressure (36.4\%) at $0.8 \mathrm{MPa}$ and under the influence of microwave radiations (24.6\%) at $210 \mathrm{~W}$ microwave power. Graft copolymers were characterized with FTIR spectroscopy, scanning electron microscopy (SEM), thermal analysis (TGA/DTA) and X-ray diffraction (XRD). Thermal stability of flax decreases on grafting under different reaction conditions. In case of XRD studies, cellulose crystals are better oriented in flax fiber followed by Flax-g-poly(MMA)-MWR, Flax-g-poly(MMA)-UP and Flax-g-poly(MMA)-IA.
\end{abstract}

Keywords: thermal properties, IR, SEM, XRD

\section{Introduction}

Modification of natural or synthetic polymers with the aim of imparting specific properties to the product has given a great thrust to macromolecular science. Desirable and targeted properties can be imparted to the natural or synthetic polymers through graft copolymerization in order to meet-out the requirement of specialized applications. It is a convenient and clean mean for altering the properties of numerous polymer back-bones. Mishra and Tripathy [1] reported the grafting of vinyl monomers onto natural fibers using peroxy diphosphate-tartaric acid redox system. Methyl acrylate was graft copolymerized onto cellulose in alkaline aqueous solution by using potassium ditelluratoargentate (III) redox system. The evidence of grafting was obtained from IR spectra and gravimetric analysis. Thermal stability, crystallinity and mor- phology of the graft copolymers were also studied [2]. Modifying the properties of natural polymers through graft copolymerization has been reported by various workers [3-13].

Since the grafting under pressure and microwave radiations is meagerly reported in literature, so in the present manuscript, we report the grafting of MMA onto flax under different reaction conditions and a comparative study has been made.

\section{Experimental}

\subsection{Materials}

Flax fiber was obtained from the Department of Agronomy, Chaudhary Sarwan Kumar Himachal Pradesh Krishi Vishwavidyalaya, Palampur (H. P.) India. 
MMA (Fluka) was washed with 5\% sodium hydroxide followed by water and was dried over anhydrous sodium sulphate. The dried monomer was distilled and the middle fraction was used. Ferrous ammonium sulphate ( $\mathrm{S}$ d Fine) was recrystallized from hot water. Hydrogen peroxide $(30 \% \mathrm{~W} / \mathrm{V}$, Qualigens Fine Chemicals) was used as received.

\section{2 .Methods}

\subsubsection{Purification of flax fiber}

Flax fiber was purified by Soxhlet extraction with acetone for 72 hours and was dried at room temperature.

\subsubsection{Infra red spectroscopy (IR)}

IR spectra of the ungrafted and grafted flax fiber were taken with $\mathrm{KBr}$ pellets on PERKIN ELMER RXI Spectrophotometer.

\subsubsection{Scanning electron microscopy (SEM)}

Scanning electron microscopic studies of flax and its graft copolymers were carried-out on Electron Microscopy Machine (LEO 435 VP). Since cellulose has non conducting behaviour so it was gold plated in order to prevent charge buildup on the sample. Scanning was synchronized with microscopic beam in order to maintain the small size over large distance relative to the specimen. The resulting images had a great depth of the field. A remarkable three-dimensional appearance with high resolution was obtained. The scans could easily verify the fact that cellulosic fibers lying apart in raw sample started forming bundles in the graft copolymers.

\subsubsection{Thermogravimetric analysis/differential thermal analysis (TGA/DTA)}

Thermogravimetric analysis and differential thermal analysis studies were carried-out in air at a heating rate of $10^{\circ} \mathrm{C} /$ minute on a thermal analyzer (LINSEIS, L-81 11).

\subsubsection{X-ray diffraction (XRD) studies}

$\mathrm{X}$-ray diffraction studies were performed under ambient conditions on Bruker- $\mathrm{D}_{8}$ advance model using $\mathrm{CuK}_{\alpha}(1.5418 \AA)$ radiation, Ni-filter and scintillation counter as detector at $40 \mathrm{kV}$ and $40 \mathrm{~mA}$ on rotation between 5 to $50^{\circ}$ at $2 \theta$ scale at 1 second step size and increment of 0.01 degree with $0.5^{\circ}$ or $1.0 \mathrm{~mm}$ of divergent and anti-scattering slit. The small particle size of each sample of Flax-g-copolymers and flax fiber was made. Each sample was homogenously mixed prior to subjecting it for X-ray diffractometry.

The randomly oriented powdered sample with a uniform surface was exposed to X-rays from all possible planes of the sample and then measuring the scattering angle of the diffracted X-rays with respect to the angle of the incident beam. The continuous scans were taken and relative intensity was obtained. Crystallinity index (C.I.), which measures the orientation of the cellulose crystals in a fiber to the fiber axis, was determined by using the wide angle $X$-ray diffraction counts at $2 \theta$ angle close to 22 and $18^{\circ}$. The counter reading at peak intensity at $22^{\circ}$ is said to represent the crystalline material and the peak intensity at $18^{\circ}$ corresponds to the amorphous material in cellulose material [14, 15]. Percentage crystallinity (\%Cr) [16] and crystallinity index (C.I.) $[17,18]$ were calculated according to Equations (1) and (2):

$$
\begin{aligned}
& \% \mathrm{Cr}=\frac{I_{22}}{I_{22}+I_{18}} \cdot 100 \\
& \text { C.I }=\frac{I_{22}-I_{18}}{I_{22}}
\end{aligned}
$$

where $I_{22}$ and $I_{18}$ are the crystalline and amorphous intensities at $2 \theta$ scale close to 22 and $18^{\circ}$, respectively.

\subsubsection{Graft copolymerization of methyl methacrylate onto flax fiber}

Grafting of MMA onto flax in air was carried out at water-bath with a range of temperatures $\left(35-75^{\circ} \mathrm{C}\right)$. Grafting under pressure was carried out in autoclave at various pressures $(0.5-1.7 \mathrm{MPa})$. Graft copolymerization of MMA onto flax under the influence of microwave radiations was carried out in microwave reactor at $210 \mathrm{~W}$ microwave power. Microwave frequency used was $2450 \mathrm{MHz}$. Flax fiber $(500 \mathrm{mg}$ ) was immersed in $100 \mathrm{ml}$ of distilled water for 24 hours prior to its grafting. A definite ratio of Fenton's reagent was added to the 
reaction flask as an initiator. A known amount of monomer was added to the reaction mixture, which was stirred constantly for a definite period of time. After the completion of reaction, the reaction flask was taken-out. The graft copolymer was Soxhlet extracted with acetone for about 5-6 hours so as to remove homopolymer. Further, the traces of homopolymer were separated from graft copolymer by stirring the graft copolymer in acetone for about 24 hours using magnetic stirrer. After homopolymer extraction, grafted fiber was dried in oven at $50^{\circ} \mathrm{C}$ till a constant weight was obtained and percentage graft yield was calculated. Different reaction parameters such as monomer concentration, initiator ratio, reaction temperature, reaction pressure, reaction time and $\mathrm{pH}$ were optimized so as to get maximum graft yield. Percentage graft yield $\left(P_{g}\right)$ was calculated by Equation (3):

$P_{g}=\frac{W_{2}-W_{1}}{W_{1}} \cdot 100$

where $W_{1}$ and $W_{2}$ are the weights of flax fiber and grafted flax, respectively.

\section{Results and discussion}

It was postulated that ferrous ammonium sulphate interacts with hydrogen peroxide to produce $\mathrm{OH}^{*}$, which is responsible for chain propagation reaction and helps in creating active sites on the polymeric back-bone where grafting can take place. In case of flax cellulose $\mathrm{C}_{2}, \mathrm{C}_{3}$ and $\mathrm{C}_{6}$ hydroxyls are the most active sites for grafting of vinyl monomers. The mechanism for the grafting of methyl methacrylate in presence of Fenton's reagent onto flax is described by Equations (4)-(10):

$$
\begin{aligned}
& \mathrm{Fe}^{2+}+\mathrm{H}-\mathrm{O}-\mathrm{O}-\mathrm{H} \longrightarrow \mathrm{OH}^{*}+\mathrm{Fe}^{3+}+\mathrm{OH}^{-} \\
& \mathrm{OH}^{*}+\mathrm{M} \longrightarrow \mathrm{OH}-\mathrm{M}^{*} \stackrel{\mathrm{nM}}{\longrightarrow} \mathrm{OH}-(\mathrm{M})_{\mathrm{n}+1}^{*} \\
& \mathrm{OH}^{*}+\mathrm{Flax}-\mathrm{H} \longrightarrow \mathrm{Flax}^{*}+\mathrm{H}_{2} \mathrm{O} \\
& \mathrm{OH}-(\mathrm{M})_{\mathrm{n}+1}^{*}+\mathrm{Flax}-\mathrm{H} \longrightarrow \mathrm{Flax}^{*}+\mathrm{OH}-(\mathrm{M})_{\mathrm{n}+1}^{*}-\mathrm{H}
\end{aligned}
$$

Flax $^{*}+\mathrm{M} \longrightarrow$ Flax $-\mathrm{M}^{*} \stackrel{\mathrm{nM}}{\longrightarrow}$ Flax $-(\mathrm{M})_{\mathrm{n}+1}^{*}$
Flax $-(\mathrm{M})_{\mathrm{n}+1}^{*}+\mathrm{OH}^{*} \longrightarrow$ Flax $-(\mathrm{M})_{\mathrm{n}+1}-\mathrm{OH}$

Flax $-(\mathrm{M})_{\mathrm{n}+1}^{*}+\mathrm{Fe}^{3+} \longrightarrow$ Flax $-(\mathrm{M})_{\mathrm{n}+1}+\mathrm{Fe}^{2+}$

where $\mathrm{M}$ denotes the monomer.

On the basis of the above mechanism, reaction sites on the back-bone polymer can be generated by the reaction between $\mathrm{OH}^{*}$ and flax fiber (Equation (6)). As is evident from Equation (4), the formation of hydroxyl free radicals $\left(\mathrm{OH}^{*}\right)$ occurs by the reaction between ferrous ion $\left(\mathrm{Fe}^{+2}\right)$ and hydrogen peroxide $\left(\mathrm{H}_{2} \mathrm{O}_{2}\right)$. The hydroxyl free radicals $\left(\mathrm{OH}^{*}\right)$ initiate the polymerization reaction to produce the growing polymeric chains (Equation (6)), which can attack the active sites of polymeric back-bone to give the graft copolymers (Equation (8)). Alternatively, the growing polymeric chains can lead to the formation of homo polymer (Equation (5)). However, the abstraction of hydrogen atom from main back-bone through Equation (6) is unlikely as the concentration of Fenton's reagent is very small. Therefore, hydroxyl free radicals will prefer to interact with vinyl monomer thereby giving growing polymeric chain which in turn creates active sites on flax back-bone by hydrogen abstraction (Equation (7)) [19]. Termination of various active species in the reaction mixture takes place by recombination (Equation (9)) and by transfer process (Equation (10)). The concentration of ferric ions $\left(\mathrm{Fe}^{+3}\right)$ in the reaction mixture plays an important role in getting the percentage grafting as it is directly involved in the termination of the reaction.

\subsection{Optimized reaction parameters for maximum graft yield}

Optimum reaction conditions for getting maximum graft yield in case of graft copolymerization of MMA onto flax fiber in air (41.7\%), under pressure (36.4\%) and under the influence of microwave radiations $(24.6 \%)$ were: $\mathrm{MMA}\left(\mathrm{mol} \cdot \mathrm{l}^{-1}\right)=$ $1.96 \cdot 10^{-3}, \mathrm{FAS}: \mathrm{H}_{2} \mathrm{O}_{2}$ (molar ratio) $=1: 6$, temperature $\left[{ }^{\circ} \mathrm{C}\right]=55$, time $[$ minutes $]=120, \mathrm{pH}=7.0$; MMA $\left(\mathrm{mol} \cdot \mathrm{l}^{-1}\right)=1.96 \cdot 10^{-3}$, FAS $-\mathrm{H}_{2} \mathrm{O}_{2}($ molar ratio $)=1: 7$, pressure $[\mathrm{MPa}]=0.8$, time $[\mathrm{min}-$ utes $]=120, \quad \mathrm{pH}=9.0$ and $\mathrm{MMA}\left(\mathrm{mol} \cdot \mathrm{l}^{-1}\right)=$ $1.96 \cdot 10^{-3}$, FAS: $\mathrm{H}_{2} \mathrm{O}_{2}$ (molar ratio) $=1: 6$, time [minutes] $=30, \mathrm{pH}=7.0$, respectively $($ Table 1$)$ $[20,21]$. 
Table 1. Optimized reaction conditions for grafting of MMA onto flax

\begin{tabular}{|l|c|c|c|c|c|}
\hline \multicolumn{1}{|c|}{ Reaction method } & $\begin{array}{c}\text { MMA concentration } \\
{[\mathbf{m o l} / \mathbf{l}]}\end{array}$ & $\begin{array}{c}\text { Reaction time } \\
{[\text { minutes] }}\end{array}$ & FAS: $\mathbf{H}_{2} \mathbf{O}_{2}$ ratio & pH & $\begin{array}{c}\text { Temperature (pressure) } \\
\text { Microwave } \\
\text { Power }\end{array}$ \\
\hline In air & $1.96 \cdot 10^{-3}$ & 120 & $1: 6$ & 7.0 & $55^{\circ} \mathrm{C}$ \\
\hline Under pressure & $1.96 \cdot 10^{-3}$ & 120 & $1: 7$ & 9.0 & $0.8 \mathrm{MPa}$ \\
\hline Under microwave radiations & $1.96 \cdot 10^{-3}$ & 30 & $1: 6$ & 7.0 & $120 \mathrm{~W}$ \\
\hline
\end{tabular}

\subsection{Comparative study of the percentage graft yield obtained in air, under pressure and under the influence of microwave radiations}

As is evident from the above results that maximum percentage grafting $(41.7 \%)$ has been observed in case of graft copolymerization carried-out in air followed by grafting under pressure $(36.4 \%)$ and under the influence of microwave radiations $(24.6 \%)$. In case of grafting in presence of microwave radiations, the electromagnetic waves which pass through the reaction medium cause the chain carrier free radicals to oscillate at a high speed, therefore, there exist a rapid collision between the different free radical species, resulting in chain termination reaction (equation (11)):

$$
\begin{array}{r}
\text { Flax } \left.-(\mathrm{M})_{n_{n+1}^{*}}^{*}+\stackrel{*}{(M}\right)_{n+1} \text { Flax } \longrightarrow \\
\text { Flax }-(M)_{n+1}(M)_{n+1} \text { Flax }
\end{array}
$$

where $\mathrm{M}=$ monomer

This leads to the formation of small molecular chain graft copolymers and resulted in getting the maximum graft yield in a short time. Hence a low graft yield was observed in case of grafting under the influence of microwave radiations.

In case of graft copolymerization carried-out under pressure though graft yield was higher than obtained in presence of microwave radiations but it was not as high as obtained in air. It is due to the fact that on carrying-out grafting under pressure, there are maximum chances of collisions of interfree radical species, thereby resulting in early decay of the propagating free radical chain and giving rise to short chain graft copolymers. Under high pressure, homopolymerization also predominates graft copolymerization, $\mathrm{OH}^{*}$ radicals preferably react with the MMA molecules and results in the termination of growing homopolymer chains (Equation (12)). Hence a low graft yield was obtained in case of grafting under pressure.

$$
\begin{aligned}
&{ }^{*} \mathrm{OH}+\mathrm{M} \longrightarrow \mathrm{OH}-\mathrm{M}^{*} \stackrel{\mathrm{nM}}{\longrightarrow} \mathrm{H}-\mathrm{O}-(\mathrm{M})_{n+1}^{*} \\
& \mathrm{HO}-(\mathrm{M})_{\mathrm{n}+1}^{*}+ \stackrel{-}{-}(\mathrm{M})_{n+1} \mathrm{OH} \longrightarrow \\
& \mathrm{HO} \longrightarrow(\mathrm{M})_{n+1}(\mathrm{M})_{\overline{n+1}} \mathrm{OH} \\
& \text { Homopolymer }
\end{aligned}
$$

In case of grafting in air, the growing free radical chains do not face rapid collision and yield long chain graft copolymers. Moreover, $\mathrm{OH}^{*}$ radicals get a lot of opportunities to strike the back-bone polymer and result in the abstraction of $\mathrm{H}$-atom, thereby, generating free radical sites on the backbone, which further propagate the graft copolymerization through interaction with monomer species Equation (13)):

$$
\begin{aligned}
& { }^{*} \mathrm{OH}+\mathrm{Flax}-\mathrm{H} \longrightarrow \text { Flax }^{*}+\mathrm{H}_{2} \mathrm{O} \\
& \text { Flax }^{*}+\mathrm{M} \longrightarrow \text { Flax }-\mathrm{M}^{*} \stackrel{\mathrm{nM}}{\longrightarrow} \text { Flax }-\left(\mathrm{M}^{*}{ }^{*}\right.
\end{aligned}
$$$$
\text { Graft copolymer }
$$

On the other hand, growing long chain monomer species attack the active sites of the back-bone polymer generating graft copolymer. Whereas, in case of graft copolymerization carried-out under pressure and under the influence of microwave radiations, the possibilities of generation of active sites on the flax back-bone are minimized due to rapid collision between the different active species, thereby, resulting in lower graft yields as compared to the grafting in air.

\subsection{Characterization of graft copolymers}

\subsubsection{Infra red spectral analysis (IR)}

IR spectrum of the flax fiber showed a broad peak at $3422.8 \mathrm{~cm}^{-1}$ due to bonded -OH group and at $2918.8,1653.5$ and $1058.7 \mathrm{~cm}^{-1}$ arising from $-\mathrm{CH}_{2}, \mathrm{C}-\mathrm{C}$ and $\mathrm{C}-\mathrm{O}$ stretching, respectively. However, in case of Flax-g-poly(MMA)-IA, Flax-gpoly(MMA)-UP and Flax-g-poly(MMA)-MWR an 
additional peak at $1734.1,1735.0$ and $1731.2 \mathrm{~cm}^{-1}$, respectively, has been observed due to $>\mathrm{C}=\mathrm{O}$ group of MMA. This suggests that MMA has been grafted onto flax through covalent linkages [20,21].

\subsubsection{Scanning electron microscopy (SEM)}

It is quite evident from Figures $1 \mathrm{a}-1 \mathrm{c}$ that there has been a sufficient deposition of poly(MMA) onto flax. Comparison of the scanning electron micrographs of flax fiber (Figure 1), Flax-g-poly(MMA)IA, Flax-g-poly(MMA)-UP and Flax-g-poly (MMA)-MWR reveals a clear cut distinction between the ungrafted and different grafted fibers $[20,21]$.
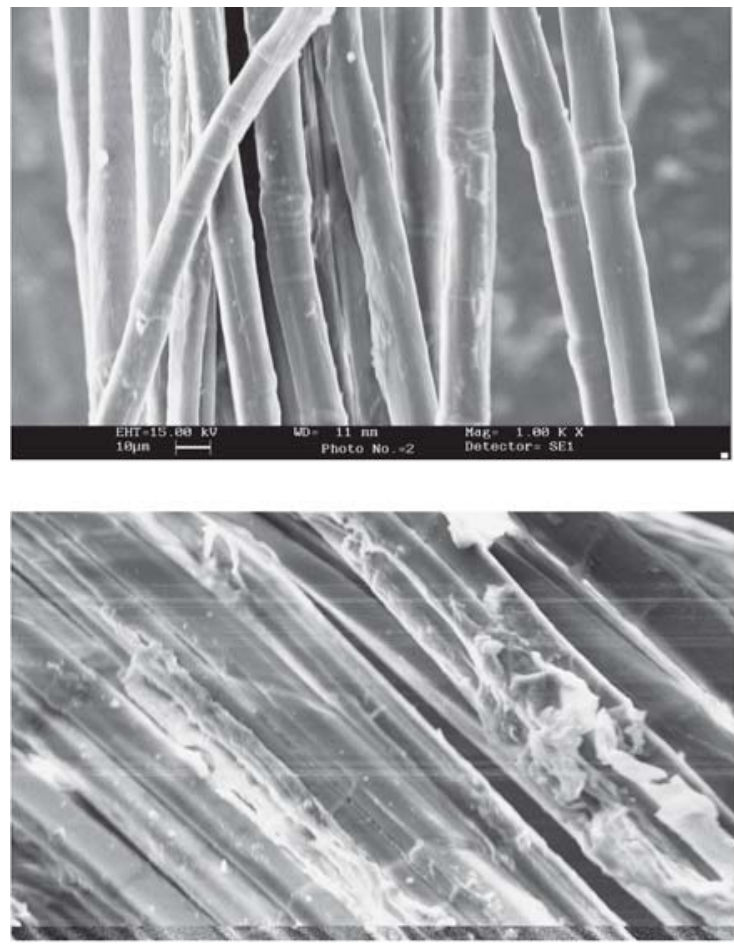

b)

\subsubsection{Thermal properties (TGA/DTA)}

Thermogravimetric analysis (TGA) is an important technique to measure the physical properties of a substance and its reaction products as a function of temperature whilst the substance is subjected to a controlled temperature program [22]. Differential thermal analysis on the other hand, is important to identify polymers, to generate phase diagram and for phase transition studies. It helps to determine melting and decomposition of organic compounds [23].

It is evident from Table 2 that initial and final decomposition temperatures of flax fiber are 279.9 and $489.1{ }^{\circ} \mathrm{C}$, respectively (Figure 2 ). Whereas, in case of Flax-g-poly(MMA)-IA, Flax-g-poly(MMA)UP and Flax-g-poly(MMA)-MWR, the initial

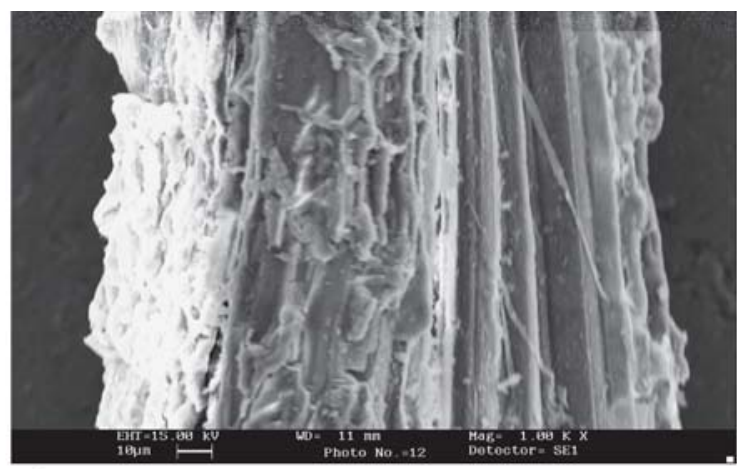

a)

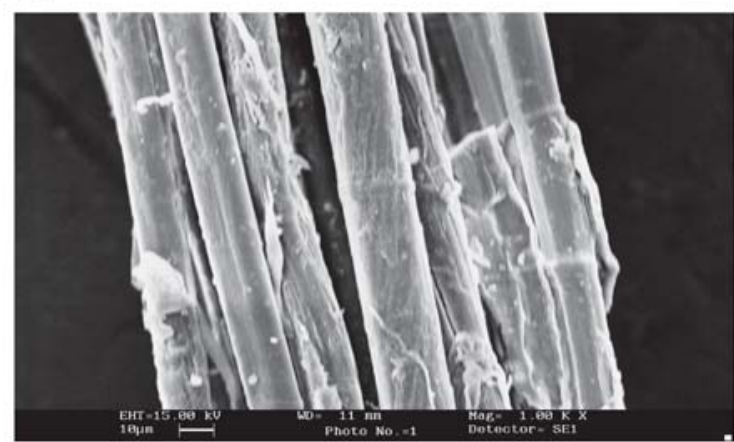

c)

Figure 1. SEM of fiber. a - SEM of Flax-g-poly(MMA)-IA, b - SEM of Flax-g-poly(MMA)-UP, c - SEM of Flax-gpoly(MMA)-MWR

Table 2. Thermal analysis of flax and its graft copolymers

\begin{tabular}{|c|l|c|c|c|}
\hline \multirow{2}{*}{$\begin{array}{c}\text { Sr. } \\
\text { No. }\end{array}$} & \multicolumn{1}{|c|}{ Sample } & \multicolumn{2}{|c|}{ TGA } & $\begin{array}{c}\text { DTA Exothermic peaks } \\
\text { at temperature }(\mu \mathrm{V})\end{array}$ \\
\cline { 2 - 5 } & \multicolumn{1}{|c|}{ IDT } & $279.9^{\circ} \mathrm{C}$ & $\begin{array}{c}325.3^{\circ} \mathrm{C}(13.8 \mu \mathrm{V}) / \\
455.3^{\circ} \mathrm{C}(38.9 \mu \mathrm{V})\end{array}$ \\
\hline 1. & Flax fiber & $212.5^{\circ} \mathrm{C}$ & $\begin{array}{c}344.9^{\circ} \mathrm{C}(20 \mu \mathrm{V}) / \\
395.2^{\circ} \mathrm{C}(19 \mu \mathrm{V})\end{array}$ \\
\hline 2. & Flax-g-poly(MMA)-IA & $436.3^{\circ} \mathrm{C}$ & $359.5^{\circ} \mathrm{C}(32.9 \mu \mathrm{V}) /$ \\
\hline 3. & Flax-g-poly(MMA)-UP & $248.1^{\circ} \mathrm{C}$ & $418.2^{\circ} \mathrm{C}$ & $393.4^{\circ} \mathrm{C}(30.7 \mu \mathrm{V})$ \\
\hline 4. & Flax-g-poly(MMA)-MWR & $207.9^{\circ} \mathrm{C}$ & $436.2^{\circ} \mathrm{C}$ & $383.7^{\circ} \mathrm{C}(41.5 \mu \mathrm{V})$ \\
\hline
\end{tabular}




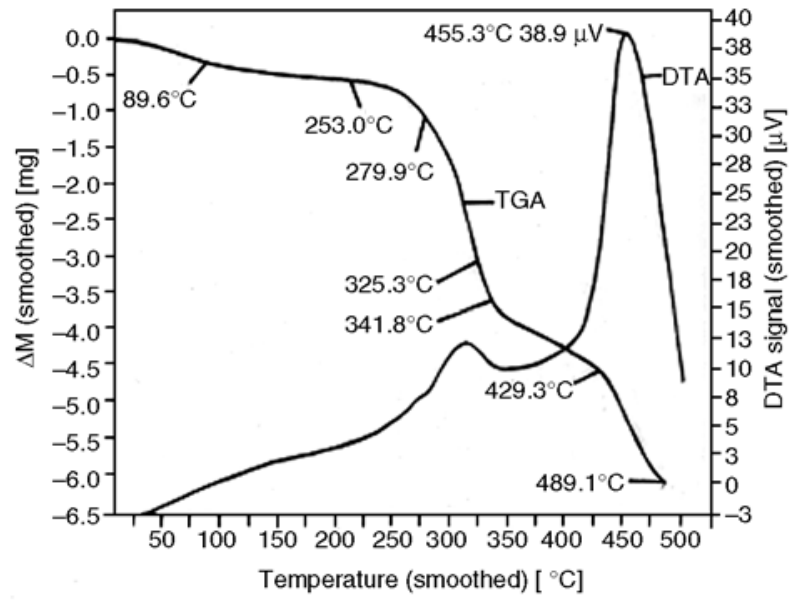

Figure 2. TGA/DTA curve of flax fiber

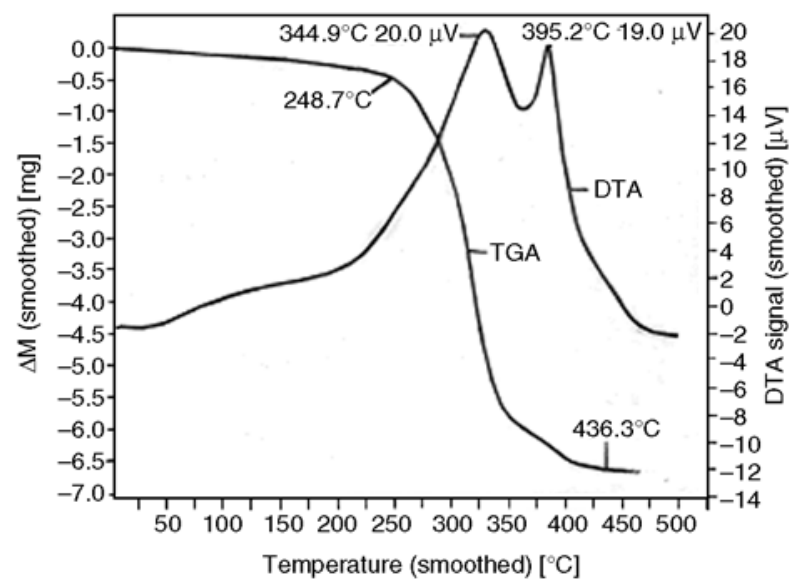

Figure 3. TGA/DTA curve of Flax-g-poly(MMA)-IA

decomposition temperatures (IDTs) are 248.7, 248.1 and $207.9^{\circ} \mathrm{C}$, respectively and the final decomposition temperatures (FDTs) are 436.3, 418.2 and $436.2^{\circ} \mathrm{C}$, respectively (Figures $3-5$ ). It is evident from the Table 2 that grafting of MMA onto flax decrease the thermal stability. It is explained on the basis that on grafting the crystalline lattice of the fiber is disturbed and the fiber becomes more amorphous, thereby resulting in lower FDTs of the graft copolymers obtained. Moreover, in case of flax fiber three stage decomposition has been observed with maximum weight loss occurring between $279.9-341.8^{\circ} \mathrm{C}(37.0 \%)$, $341.8-429.3^{\circ} \mathrm{C}(12.57 \%)$ and $429.3-489.1^{\circ} \mathrm{C}$ (22.57\%). Whereas, graft copolymers: Flax-g-poly (MMA)-IA, Flax-g-poly(MMA)-UP and Flax-gpoly(MMA)-MWR, showed single stage decomposition only with maximum weight loss of $87.71 \%$ at $436.3^{\circ} \mathrm{C}, 67.36 \%$ at $418.2^{\circ} \mathrm{C}$ and $80.55 \%$ at

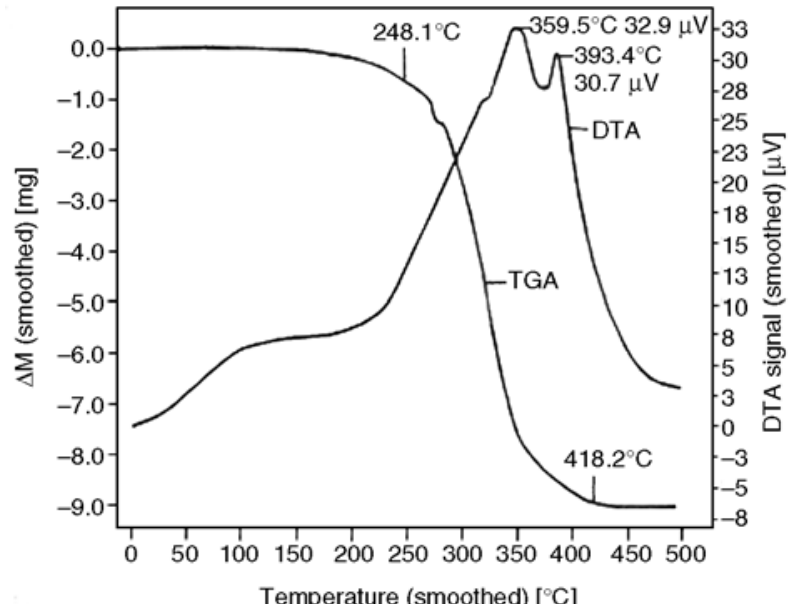

Figure 4. TGA/DTA curve of Flax-g-poly(MMA)-UP

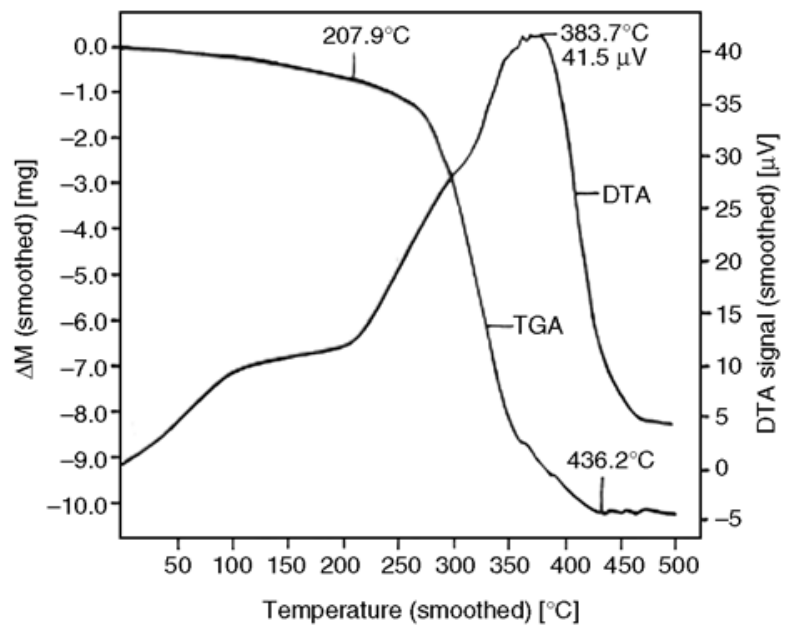

Figure 5. TGA/DTA curve of Flax-g-poly(MMA)-MWR

$436.2^{\circ} \mathrm{C}$, respectively. This can again be explained on the basis of disturbance in the crystal lattice of flax fiber on graft copolymerization. Flax fiber becomes more amorphous after grafting process. Differential thermal analysis of flax fiber showed exothermic peaks at $325.3^{\circ} \mathrm{C}(13.8 \mu \mathrm{V})$ and $455.3^{\circ} \mathrm{C}(38.9 \mu \mathrm{V})$, which indicates the complete break down of $\mathrm{C}-\mathrm{C}$ and $\mathrm{C}-\mathrm{O}$ bonds of the crystalline region (Table 2 and Figure 2). However, in case of Flax-g-poly(MMA)-IA, Flax-g-poly (MMA)-UP and Flax-g-poly(MMA)-MWR, a continuous exothermic rise in temperatures has been observed and the exothermic peaks at $344.9^{\circ} \mathrm{C}$ $(20 \mu \mathrm{V}) / 395.2^{\circ} \mathrm{C}(19 \mu \mathrm{V}), 359.5^{\circ} \mathrm{C}(32.9 \mu \mathrm{V}) /$ $393.4^{\circ} \mathrm{C}(30.7 \mu \mathrm{V})$ and $383.7^{\circ} \mathrm{C}(41.5 \mu \mathrm{V})$, respectively, have been obtained (Figures 3-5). As is evident from Table 2 that broader exothermic peak at $344.9^{\circ} \mathrm{C}(20 \mu \mathrm{V})$ as compared to the peak at $395.2^{\circ} \mathrm{C}(19 \mu \mathrm{V})$ in case of Flax-g-poly(MMA)-IA 
is the evidence of the fact that most of the crystalline portion of the flax has been disturbed during the grafting process. Similar results have been found in case of graft copolymers prepared under pressure and under the influence of MWR.

\subsubsection{X-ray diffraction (XRD) studies}

It is evident from Table 3 that flax fiber, Flax-gpoly(MMA)-IA, Flax-g-poly(MMA)-UP and Flaxg-poly(MMA)-MWR showed 77, 64, 68 and 69\% crystallinity, respectively. Crystallinity index of flax fiber, Flax-g-poly(MMA)-IA, Flax-g-poly (MMA)-UP and Flax-g-poly(MMA)-MWR has been observed to be $0.7005,0.4477,0.5207$ and 0.5502 , respectively.

The X-ray diffraction spectra of flax fiber and graft copolymers (Figure 6) were analyzed and it has been found that the spectrum of flax fiber is more convex than that of graft copolymers. In case of flax fiber, the incorporation of poly(MMA) chains to the back-bone of the flax back-bone had impaired the crystallinity of flax fiber. Therefore, on grafting $\% \mathrm{Cr}$ decreases rapidly with reduction in its stiffness and hardness [24, 25]. Whereas, graft copolymers prepared under the influence of

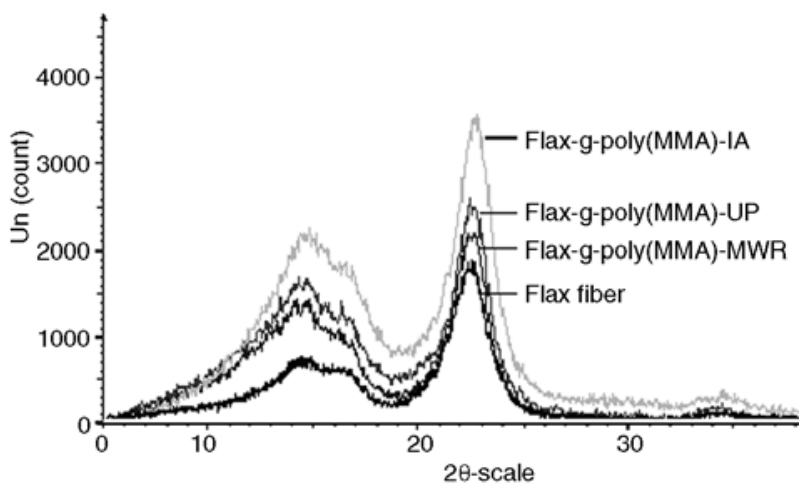

Figure 6. X-ray diffraction studies of Flax-g-copolymers vis-à-vis flax fiber microwave radiations showed a fewer changes in the crystalline lattice in comparison to graft copolymers prepared in air and under pressure. This is due to the reason that optimum reaction time for grafting under MWR was very low and thus the fiber underwent a fewer changes in its crystal structure. On the other hand, a lower crystallinity index in case of graft copolymers prepared in air and under pressure indicates poor order of cellulose crystals in the grafted fibers. C.I. of Flax-g-poly(MMA)MWR (0.5502) is higher than that of Flax-g-poly (MMA)-IA (0.4477) and Flax-g-poly(MMA)-UP (0.5207). Although C.I. gives a quantitative measure of the orientation of the cellulose crystals in fibers, X-ray diffraction patterns are visual indicators of the orientation of the cellulose crystals. The diffraction of flax fiber produces narrow and bright patterns that are characteristic of oriented crystals [26]. On the other hand, the diffraction pictures of Flax-g-poly(MMA)-IA, Flax-g-poly(MMA)-UP and Flax-g-poly(MMA)-MWR showed long diffracting arcs that end sharply. This is due to misorientation of the cellulose crystals to the fiber axis during grafting as indicated by the lower crystallinity index in Flax-g-poly(MMA)-IA, Flax-gpoly(MMA)-UP and Flax-g-poly(MMA)-MWR.

\section{Conclusions}

Grafting through micro-wave radiation technique is an effective method in terms of time consumption and cost effectiveness. Maximum percentage grafting has been observed in case of grafting carriedout in air followed by grafting under pressure and under the influence of microwave radiations. Flax faces less surface deformations during grafting process under the influence of microwave radiations as compared to grafting in air and under pressure, thereby retaining better crystalline structure.

Table 3. Percentage crystallinity (\%Cr) and crystallinity index (C.I.) of flax fiber and graft copolymers prepared under different reaction conditions

\begin{tabular}{|c|c|c|c|c|c|c|}
\hline \multirow{2}{*}{$\begin{array}{l}\text { Sr. } \\
\text { No. }\end{array}$} & \multirow{2}{*}{ Sample } & \multirow{2}{*}{$\mathbf{P}_{\mathrm{g}}$} & \multicolumn{2}{|c|}{ at $2 \theta$ scale } & \multirow{2}{*}{$\% \mathrm{Cr}$} & \multirow{2}{*}{ C.I. } \\
\hline & & & $\mathbf{I}_{22}$ & $\mathbf{I}_{18}$ & & \\
\hline 1. & Flax fiber & - & 1780 & 533 & 77 & 0.7005 \\
\hline 2. & Flax-g-poly(MMA)-IA & 41.7 & 3348 & 1849 & 64 & 0.4477 \\
\hline 3. & Flax-g-poly(MMA)-UP & 36.4 & 2944 & 1411 & 68 & 0.5207 \\
\hline 4. & Flax-g-poly(MMA)-MWR & 24.6 & 2466 & 1109 & 69 & 0.5502 \\
\hline
\end{tabular}




\section{References}

[1] Mishra M. K., Tripathy A. K.: Grafting vinyl monomers onto natural fibres. Graft copolymerization of methyl methacrylate onto wool and silk using peroxydiphosphate-tartaric acid redox system. European Polymer Journal, 17, 1225-1226 (1981).

[2] Liu Y., Yang L., Shi Z., Li J.: Graft copolymerization of methyl acrylate onto cellulose initiated by potassium ditelluratoargentate(III). Polymer International, 53, 1561-1566 (2004).

[3] Tiwari A., Singh V.: Synthesis and characterization of electrical conducting chitosan-graft-polyaniline. Express Polymer Letters, 1, 308-317 (2007).

[4] Eromosele I. C., Hamagadu T. J.: Graft copolymerization of methylmethacrylate onto caesarweed fibers by the potassium permanganate-toluene redox system. Journal of Applied Polymer Science, 50, 645-649 (1993).

[5] Bhattacharya A., Misra B. N.: Grafting: A versatile mean to modify polymers techniques, factors and applications. Progress in Polymer Science, 29, 767814 (2004).

[6] Bhattacharyya S. N., Maldas D.: Graft copolymerization onto cellulosics. Progress in Polymer Science, 10, 171-270 (1983).

[7] Wielen L. C. V., Ragauskas A. J.: Grafting of acrylamide onto cellulosic fibers via dielectric-discharge. European Polymer Journal, 40, 477-482 (2004).

[8] Margutti S., Vicini S., Proietti N., Capitani D., Conio G., Pedemonte E., Segre A. L.: Physical-chemical characterization of acrylic polymers grafted on cellulose. Polymer, 43, 6183-6194 (2002).

[9] Sabaa M. W., Mokhtar S. M.: Chemically induced graft copolymerization of itaconic acid onto cellulose fibers. Polymer Testing, 21, 337-343 (2002).

[10] Singh V., Tiwari A., Pandey S., Singh S. K.: Peroxydisulfate initiated synthesis of potato starch-graftpoly(acrylonitrile) under microwave irradiation. Express Polymer Letters, 1, 51-58 (2007).

[11] Kaith B. S., Kumar K.: In air synthesis of Psy-clpoly(AAm) network and its application in waterabsorption from oil-water emulsions. Express Polymer Letters, 1, 474-480 (2007).

[12] Princi E., Vicini S., Proietti N., Capitani D.: Grafting polymerization on cellulose based textiles: ${ }^{13} \mathrm{C}$ solid state NMR characterization. European Polymer Journal, 41, 1196-1203 (2005).

[13] Tsukada M., Islam S., Arai T., Boschi A., Freddi G.: Microwave irradiation technique to enhance protein fibre properties. Autex Research Journal, 5, 40-48 (2005).
[14] Wakelin J. H., Virgin H. S., Crystal E.: Development and comparison of two X-ray methods for determining the crystallinity of cotton cellulose. Journal of Applied Physics, 30, 1654-1662 (1959).

[15] Mwaikambo L. Y., Ansell M. P.: Chemical modification of hemp, sisal, jute, and kapok fibers by alkalization. Journal of Applied Polymer Science, 84, 2222 2234 (2002).

[16] Agrawal A. M., Manek R. V., Kolling W. M., Neau S. H.: Studies on the interaction of water with ethylcellulose: Effect of polymer particle size. AAPS PharmSciTech, 4, 11 pages in Article 60 (2003).

[17] Reddy N., Yang Y.: Structure and properties of high quality natural cellulose fibers from cornstalks. Polymer, 46, 5494-5500 (2005).

[18] Segal L. C., Creely J. J., Martin A. E., Conrad C. M.: An empirical method for estimating the degree of crystallinity of native cellulose using the X-ray diffractometer. Textile Research Journal, 29, 786-794 (1959).

[19] Misra B. N., Chandel P. S., Dogra R.: Grafting onto wool. III. Graft copolymerization of poly(vinyl acetate) by use of Fenton's reagent as initiator. Journal of Polymer Science: Polymer Chemistry Edition, 16, 1801-1805 (1978).

[20] Kaith B. S., Singha A. S., Kumar S., Misra B. N.: FAS- $\mathrm{H}_{2} \mathrm{O}_{2}$ initiated graft polymerization of methylmethacrylate onto flax and evaluation of some physical and chemical properties. Journal of Polymer Materials, 22, 425-432 (2005).

[21] Kaith B. S., Kalia S.: Preparation of micro-wave radiation induced graft copolymers and their applications as reinforcing material in phenolic composites. Polymer Composites, In press (2008).

[22] Mackenzie R. C.: Nomenclature in thermal analysis, part IV. Journal of Thermal Analysis and Calorimetry, 13, 387-392 (1978).

[23] Skoog D. A., Holler F. J., Nieman T. A.: Principles of instrumental analysis. Saunders Golden Sunburst Series, Philadelphia (2001).

[24] Billmeyer F. W. Jr.: Textbook of polymer sciences. Wiley and Sons, New York (1984).

[25] Morton E. W., Hearle J. W. S.: Physical properties of textile fibers. The Textile Institute, Manchester (1993).

[26] Cao J., Billows C. A.: Crystallinity determination of native and stretched wool by X-ray diffraction. Polymer International, 48, 1027-1033 (1999). 